\title{
North Carolina Books
}

\author{
Robert Anthony, Compiler
}

William S. Powell. North Carolina through Four Centuries. Chapel Hill: University of North Carolina Press, 1989. 652 pp. \$29.95. ISBN 0-8078-18461. or ISBN 0-8078-1850-X (text ed.).

Considering how widely read and studied was the predecessor to this volume, it may be inevitable that William S. Powell's new history of North Carolina will at first be referred to as "the new Lefler and Newsome." Indeed, Powell was a student and colleague of Hugh Lefler, and it was Dr. Lefler's express wish that Powell be asked to write the state history that would update his own classic text first published thirty-five years ago. The result, however, is no mere reworking of the previous volume. Drawn from a lifetime's experience in teaching and writing about the history of this state, Powell's North Carolina Through Four Centuries is entirely his own -fresh, remarkably comprehensive, and a delight to read.

Professor Powell is probably the best known contemporary historian of North Carolina, and his whole career has prepared him for the writing of this book. Librarian and curator of the North Carolina Collection at the University of North Carolina at Chapel Hill for many years, he also taught history there from 1964 to 1987, compiled The North Carolina Gazetteer and the Dictionary of North Carolina Biography, has written and edited a variety of books on the state's history, has published innumerable articles, and also has lectured extensively.

The author's thorough enjoyment of North Carolina history is evident on every page of this work. His familiarity with the material has allowed him to write in a style less formal than that commonly found in textbooks, but no less scholarly. The facts are clearly presented, specific events described and set in context, and broad changes defined and discussed. Yet the voice, tales, and comments are distinctly Powell's, as if the reader were sitting in his classroom. Whether characterizing the prominent figures in the Regulator movement, the personalities involved in the Kirk-Holden War, or Harriet Berry of the Good Roads Association, he never allows the reader to forget the humanity of those who participated in historic events. In descriptions such as that of Sherman's army crossing into the state, he conveys a remarkable sense of what it must have been like.

The volume begins with the land and native peoples and covers the sweep of events through to the late $1980 \mathrm{~s}$, with a final chapter discussing "NC2000," the findings in 1983 of the Commission on the Future of North Carolina. Overall, a good balance between political and social history is maintained. There are some separate chapters on social history, such as "Colonial Society and Culture, 1729-1776," but it is frequently interwoven with the political history, as in the sections on North Carolina after the Civil War. Some of the events that have profoundly changed North Carolina in the latter half of the twentieth century are discussed in depth, such as mileposts in the civil rights movement, the Vietnam War, student unrest, Research Triangle Park, environmental concerns, etc. But the treatment of these years is rather uneven. National context is given for most of the events in North Carolina, but somehow Martin Luther King, Jr., and the assassination of President Kennedy escape mention, though both surely affected North Carolinians. The history of Indian North Carolinians is given by tribe in the first chapter. This is a useful arrangement in some ways, but Indians are only occasionally referred to in the rest of the text. The "Trail of Tears" is discussed, but not Henry Berry Lowry or separate school systems for Indians as well as Negroes. Also, one could wish for more on the role of women before the twentieth century.

Nonetheless, this is a remarkably useful and attractive book. The illustrations are excellent, including many that have not been used before as well as some of the old standards. Maps, tables, and graphs supplement the text at judicious points. Informative captions make all the illustrations independently interesting. Appendices include a list of the British monarchs during colonial times; a list of governors; information about the counties; population statistics; sites of meetings of the legislature; and a chronology of North Carolina history considerably expanded and improved over the one in Lefler and New- 


\section{North Carolina Books}

some. The essay on further reading and the bibliography are very helpful, and the book ends with a fine index.

North Carolina Through Four Centuries is certainly destined to be a classic like its forerunner. It succeeds as an academic text, as a scholarly reference work, and as a very enjoyable book for the history buff. Students from junior high school on up would find it helpful. It will certainly be in academic libraries in and beyond the state, and it should be made available in public libraries as well. It is appropriate that Powell has dedicated this book to his grandchildren. They and others like them will be enjoying the fruits of his labors for many years to come.

\section{Barbara T. Cain, North Carolina State Archives}

Jon Lee Wiggs. The Community College System in North Carolina: A Silver Anniversary History, 1963-1988. Raleigh: North Carolina State Board of Community Colleges, 1989. 421 pages. Limited number of copies available free from the North Carolina Department of Community Colleges, Caswell Building, 200 W. Jones Street, Raleigh, 27603-1337.

The North Carolina Community College System was created by the Omnibus Higher Education Act of 1963, a significant piece of educational legislation arising from the recommendations of Governor Terry Sanford's Commission on Education Beyond the High School. The Carlyle Report, named for the chairman of the Commission, made several recommendations regarding the future of higher education in North Carolina, not the least of which was the merger of the dual systems of state industrial education centers and public junior colleges to form the North Carolina Community College System. This system was to be governed by the State Board of Education, administered by a Department of Community Colleges, with local, twelve-member boards of trustees administering the individual institutions.

It is the history of the Community College System, therefore, that serves as the focus of this North Carolina State University doctoral dissertation written by Jon Wiggs and published by the North Carolina State Board of Community Colleges in celebration of the twenty-fifth anniversary of the founding of the system. It is a chronological recounting of the development and growth of this fifty-eight college system during the first quarter century of its existence. Wiggs examined such records as the minutes of the North Carolina State Board of Education, which gov- erned this system until 1981; the minutes of the North Carolina State Board of Community Colleges; the Raleigh New and Observer; special reports and documents indigenous to the system and prepared during the period covered; and numerous doctoral dissertations which have examined various aspects of the North Carolina community colleges.

Wiggs does analyze some of the issues and political maneuverings that have been part of the system's development, but primarily he has assembled the historical facts of its growth through 1988 and structured them in a manner which highlights the terms of the five administrative heads of the system: Dr. Isaac Epps Ready, director, 1963-1970; Dr. Ben E. Fountain, Jr., director and then president, 1971-1978; Dr. Charles R. Holloman, senior vice-president in charge, 1978-1979; Dr. Larry J. Blake, president, 1979-1983; and former governor Robert W. Scott, president, 1983-

The major weaknesses in this work are that it does not relate the history of the North Carolina Community College System to the development of other community colleges in the country and that it provides only limited critical analysis. As the author states in the preface, however, he did not intend to do this. Rather, he wanted to provide a "qualitative data base" for the system's history and tried "to capture the facts and present them as objectively and straightforwardly as possible."

Two strengths of the book are its bibliographies of works cited and of dissertations which have been written about the community colleges in North Carolina. There are key word and chronological indexes to these dissertations and subject and name indexes to the book's contents.

The Community College System in North Carolina is an important work because it is the first published history of the system, because it adds significantly to the history of higher education in North Carolina, and because of its contribution to the history of the community college movement in this country-a national movement that now enrolls forty-three percent of all undergraduate students in the United States.

Beverly Gass, Guilford Technical Community College

Wilma Dykeman. The Tall Woman. Newport, Tenn.: Wakestone Books, c.1962, 1988. 315 pp. \$8.95. ISBN 0-9613859-1-X (pbk.).

The Tall Woman: A Commentary by Wilma Dykeman. Newport, Tenn.: Wakestone Books, 1989. $1 / 2^{\prime \prime}$ VHS. 33 minutes. Color videotape. $\$ 89.50$. ISBN 0-9613859-6-0. 
Wilma Dykeman. The Far Family. New York: Holt, Rinehart and Winston, c.1966, 1988. 372 pp. $\$ 14.95$. ISBN 0-9613859-4-4. Orders to Wakestone Books, 405 Clifton Heights, Newport, Tenn. 37821.

The year is 1864. Lydia Moore McQueen is an eighteen-year-old newly married woman, pregnant with her first child, who lives in a small isolated North Carolina mountain community called Thickety Creek. Her husband has joined the Union Army while her brother and father are both fighting for the Confederacy. One night her brother comes to tell her that her mother and younger brothers and sisters have been attacked by renegades who have run off all the livestock and tortured her mother. Lydia moves in with them to keep the family and the farm going. Before the war is over, she is forced, while heavily pregnant, to plow the fields using the milk cow in order for there to be a corn crop.

This is what life is like for Lydia McQueen at the beginning of Wilma Dykeman's The Tall Woman, the classic North Carolina novel recently re-released by Wakestone Books. The titular character, Lydia, is continually faced with adversity but her indomitable spirit and determination enable her to persevere. As the novel continues, we see the Moores and McQueens confronted by one hardship after another: Lydia's brother loses an arm in the Civil War, her husband is a prisoner at Andersonville Prison, and her first child is born mildly retarded.

But Lydia and her family manage to cope with all the hardships. After the war, Lydia and her husband Mark move further up into the mountains to homestead, and each year finds them a little more settled and secure with their growing family. Even when Mark's restlessness causes him to go out west and leave Lydia and the children for over a year, Lydia's strength of character and her sense of purpose see her through.

One of Lydia's primary concerns is education. She believes that it is extremely important for all children to be educated, and she fights to establish a school with a regular teacher in their community. When the school is deliberately burned to the ground, she is the driving force behind getting a new school built for the students, even resorting to a little polite blackmail to accomplish her purpose.

At the end of the novel, Lydia dies at the age of fifty of typhoid fever. While she is on her deathbed, the mountain people gather at her cabin to offer their help. One by one, they begin to tell of the influence Lydia has had on their liveshow she helped bring their children into the

\section{North Carolina Giving: The Directory of the State's Foundations}

\author{
North Carolina Giving is \\ the most complete, authoritative guide \\ to the state's more than 700 private \\ charitable and community foundations. \\ It is a vital resource for nonprofit \\ organizations and institutions, or for \\ anyone seeking grants.
}
North Carolina Giving provides all the information that is needed to easily identify appropriate funding sources. The directory is cross- referenced with indexes by county, areas of interest and board members, saving you countless hours of research. Order your copy of this limited edition today.

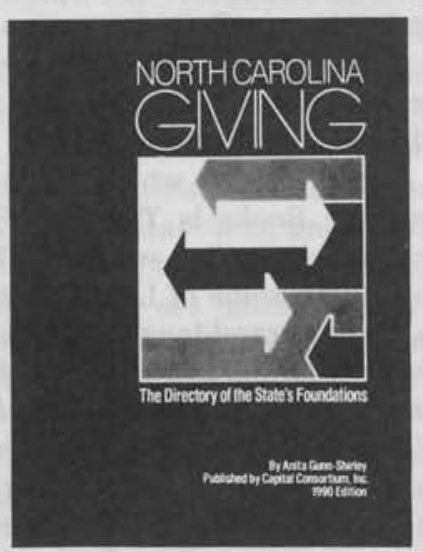

ISBN: 0-9624910-0-4
Please send me copies of North Carolina Giving at $\$ 99.00$ per copy: Enclosed is my check for $\$$

Return to: North Carolina Giving, Capital Consortium, P0 Box 2918, Raleigh, North Carolina 27602 919/833-4553
Name:

Title:

Organization:

Address:

Phone: 
world and nursed young and old through disease and death. The old mountain saying, "A tall woman casts a long shadow," had turned out to be true of Lydia Moore McQueen.

The story of Lydia and her struggles and triumphs is a compelling one; it is well told and the characters seem to come to life on the page. There is a judicious use of dialect so that the reader gets a feel for how the people spoke, but it is not so overdone that the reader gets bogged down. The Tall Woman is an authentic depiction of mountain life in the South during the latter half of the nineteenth century. Mountain life and mountain lore are meticulously described. From the planting of crops to the gathering of herbs and the cooking of local produce and game, everything is told in rich and exact detail. This authenticity, combined with the powerful story itself, have made the book a popular choice for study in schools throughout the Southeast.

A videotape entitled The Tall Woman: A Commentary by Wilma Dykeman has been produced by Wakestone Books to accompany and augmen $\hat{\imath}$ the study of the novel. This thirty-threeminute color videotape is narrated by Wilma Dykeman herself. She reads critical passages from the novel and discusses some of the characters and situations. In addition, the video vividly depicts the mountains of North Carolina, showing a cabin of the type in which Lydia McQueen would have lived as well as the surroundings, climate, and wildlife. The video helps to evoke the atmosphere of the novel so that scenes come even more vividly to life for the reader.

A second book which has been reissued by Wakestone Books is The Far Family, also by Wilma Dykeman. As a sequel to The Tall Woman, it deals with some of Lydia McQueen's descendants. Lydia's granddaughter Ivy who is mentioned in the last paragraph of The Tall Woman is the main character in The Far Family. She and her family, the Thurstons, grew up in the mountain area of Thickety Creek, but over the years have drifted away to other parts of the country. One of Ivy's sisters lives in New England and another in South Carolina. Clay, one of her brothers, has just returned from many years in the North. Ivy and her other brother have continued to live in the mountains. Their mother, Martha, Lydia's oldest daughter, is still alive and in her nineties. Ivy's son, Phil Cortland, is a United States Senator in Washington.

As the novel opens, Ivy is happily looking forward to a visit from Phil, but the anticipation soon gives way to fear and uncertainty. A black man has been shot and killed in rather mysterious circumstances. All the evidence points to Clay Thurston as the killer, but he was too drunk at the time to remember exactly what happened. There will have to be a hearing into the matter, and everyone is immediately concerned about its effect on the family. The family begins to gather and rally around to face this new adversity. They are a very diverse group of people who have little in common but their family ties.

The novel is told with frequent flashbacks to when they all still lived on Thickety Creek. Characters who were first introduced in The Tall Woman reappear as the current generation reminisces. Ivy and her family use the present crisis to reflect on their roots. They once again realize their mutual heritage and begin to gain more respect for one another.

Although The Far Family is a sequel to The Tall Woman, it is not nearly as significant. The Tall Woman is an exceptional novel with indepth characterization and a plot that focuses on a struggle for survival. The Far Family, while "a good read," does not have the scope or appeal of the earlier book. It is the story of a contemporary family that faces contemporary problems: suicide, alcoholism, abortion. Of course these problems are not unique to the twentieth century. But in The Tall Woman the focus is on one woman and how she overcomes the adversities she faces. Lydia's personality is such that she dominates the book, and the reader comes away with a lasting impression of strength and courage.

\section{Diane Kessler, Neal Junior High School, Durham}

Alton Ballance. Ocracokers. Chapel Hill: University of North Carolina Press, 1989. 255 pp. \$22.95. ISBN 0-8078-1878-X (cloth); \$8.95. 0-8078-4265-6 (paper).

Ocracoke native Alton Ballance began writing Ocracokers while a student at the University of North Carolina at Chapel Hill in the late 1970s. Although much has been written about this special place, little of it has presented "Ocracoke as most Ocracokers know it." A descendant of some of the first settlers, Ballance grew up on the island and returned in 1982 to teach at Ocracoke School after having taught two years in Hillsborough, N.C. Also a Hyde County Commissioner, he is uniquely qualified to write this book about "Ocracoke and Ocracokers, past and present, and how both have adapted to the changes that have taken place within the last few years."

The book is divided into three parts, each of which contains several chapters. The first part 
discusses the land and the sea, early history and settlement, shipwrecks and lifesaving stations. The second part tells the stories of ordinary people, often expressed poignantly in their own words. It is through people like Uriah and Sullivan Garrish, who taught the author the art of mullet fishing, that the reader gains the greatest appreciation of what Ocracoke is really like. Other special people are presented in chapters on hunting, health care, religion, and education. The final part, "Building Bridges," discusses the National Park Service, hurricanes, World War II, transportation services, and tourism. It concludes with a discussion of the issues and problems confronting the island today.

Throughout the book, Ballance interweaves the past and the present, for they cannot be truly separated. He concludes, however, with a look to the future. The last decade has seen tremendous growth and change, as symbolized by the construction of a new water tower in 1977. Ballance is optimistic about Ocracoke's survival, although it will require planning and acceptance of change, however difficult that may be. As he states, it is the "children of transition," such as himself, "who must balance the old ways and the new and go on living in the village beneath the lighthouse and the water tower."

The author has done an excellent job of capturing the special qualities of Ocracoke and its people, both in the past and the present. Quotations from residents have been used adeptly to add interest and insight. Ballance includes some discerning comments of his own that help the reader understand Ocracokers and the challenges that have confronted them in the past and the new challenges that confront them for the future.

Although some of the content is based on historical research, much of the book is written from the author's own experiences and interviews of people. It is not meant to be a scholarly book; thus, there are no footnotes or bibliography (although a short one would have been useful) but there is an index. The book is illustrated with both historical and contemporary photographs of people, places, and everyday things that complement the text. The style in which it is written makes the book especially suitable for public libraries, but all types of libraries that select North Caroliniana should consider acquiring it. Ocracokers also would make an excellent gift for anyone who has ever visited or lived there and has a special affinity for the island and its people.

Cheryl W. McLean, State Library of North Carolina
Ginny Turner, ed. North Carolina Traveler: $A$ Vacationer's Guide to the Mountains, Piedmont and Coast. Chapel Hill: Ventana Press, 1989. 362 pp. \$9.95. ISBN 0-940087-30-8 (pbk).

North Carolina Traveler is a well-organized and informative guide to the Tar Heel state. The book is divided into the three obvious regions of the state, then each region is subdivided into smaller sections to describe specific areas of North Carolina. The listings are in geographic order, beginning in the east and moving to the west, with a north to south progression within each region.

The guide was edited by Ginny Turner with contributions by Edgar and Patricia Cheatham, Rick Mashburn, and Ginger Moore. It is written in a narrative, informal, and folksy style, with sprinklings of humor. While this book is fascinating to read, it would be very useful as a reference guide.

The organization of the sections, with distinctive typography for each subsection, makes it easy to scan for information. Each section begins with a discussion of the location with emphasis on topography and history. Next, the section is subdivided by area and then by community. Visitor information lists visitors bureaus, newspapers, and events calendars. Access information explains exactly how to get to sites, including highway numbers and distance from other towns, as well as the locations of airports, train stations, and bus stations. Attractions include historic places, tours, museums, special shopping, cultural offerings, recreation, and seasonal events. Side trips entries discuss nearby communities. Accommodations lists hotels, inns, restaurants, and nightlife in each community. Three to six entries for each type of accommodation are given usually in expensive, moderate, and inexpensive price ranges. Price range citations refer to a key in the introduction.

Each entry, whether a newspaper or historic site or restaurant, gives the address and telephone number. When applicable, admission prices are given and the hours of operation and months of special interest are shown. Cross references allow an entry to be listed in more than one location.

Black-and-white photographs with brief titles are scattered throughout the book. The double-page highway map on the title page is followed by maps of the three regions and of several cities. A small outline map of the state, with the subject of that section marked in black, introduces each section and subsection, reminding the reader constantly of the location being discussed. 


\section{North Carolina Books}

The appendix lists addresses and telephone numbers of useful agencies in the state as well as toll free numbers for hotel chains, transportation agencies, and car rental companies. Other useful facts include summer and winter average temperatures for various towns and ferry schedules. The detailed index provides quick reference to any topic, site, or geographic area.

The coverage is thorough and would be especially valuable to a person who wants to spend some time in an area. Numerous useful bits of information are included, such as the availability of a pet kennel at Carowinds. Information provided is current, including the 1988 Nobel Prize award to two researchers who work with Burroughs-Wellcome and the 1989 debut of the Charlotte Knights baseball team in a new stadium.

Even though the coverage is extensive, it has omitted some of this reviewer's favorite towns, as well as all of the western coastal plain. Some great events are omitted, such as First Night Charlotte, a New Year's Eve celebration which attracts seventy-five thousand people to uptown Charlotte, and many excellent restaurants are not listed.

Some of the information in the book is available in other sources. The AAA guide to North Carolina gives more hotels and restaurants, with evaluations, prices, telephone numbers and addresses, but does not discuss each in the detail shown here. North Carolina, a Guide to the Old North State by Federal Writers Project, published in 1939, gives a good historical account of many localities. Marguerite Schumann's The Living Land: an Outdoor Guide to North Carolina, published in 1977, gives more information about topography and history of outdoor areas. The Division of Travel and Tourism of the North Carolina Department of Commerce publishes guides to the state with information about accommodations, convention space, and access for disabled persons, which tend to be accurate and timely. The Division of Archives and History in the Department of Cultural Resources publishes directories of historic sites and calendars of events. The North Carolina transportation map, published by the North Carolina Department of Transportation, includes many useful facts. But no other publication includes so much information in one place as is contained in this book. It has everything needed to travel across and around the state.

This book is recommended for every library in the state, regardless of type. It will be popular among patrons for local information about the hometown and for assistance when traveling. Since it will be popular, most libraries may want to reinforce or rebind the paper binding. This reviewer plans to keep a copy in the car for reference when traveling and to give copies to family and friends.

\section{Elizabeth J. Laney, University of North Carolina at Chapel Hill}

David Payne. Early from the Dance. New York: Doubleday, 1989. 492 pp. $\$ 18.95$. ISBN $0-385-$ 26417-8.

At thirty-two, Adam Jenrette has achieved success as an artist, but lately his life has taken a precipitous downward turn. Unfavorable reviews and personal unhappiness have triggered his frenetic involvement in the New York demimonde and his binges with alcohol and cocaine. Adam's creativity and motivation have all but evaporated. A telephone call from an attorney beckons him home to Killdeer, North Carolina, to attend his aunt's funeral and discover her legacy to him. During the visit he sees Jane for the first time since the remarkable summer they spent at the North Carolina coast thirteen years earlier. The events of that summer may have lead to the suicide of Cary, Adam's best friend and Jane's boyfriend.

When they first renew their relationship, Adam and Jane circle each other verbally in a sort of prickly erotic dance. They seem emotionally handicapped, unable to express a thought or feeling without a heavy camouflage of hostile witticisms. Adam is morbidly (and tiresomely) obsessed with Cary's suicide. This reviewer found their behavior extremely aggravating. One of the triumphs of Payne's writing is that, as he reveals the characters' history, one not only understands this conduct, but also comes to empathize with the pain and confusion that they experience upon seeing one another.

Payne tells their story in a series of first-person flashbacks. The central crisis comes when the three young people decide to spend the summer working at the beach. At the last minute Cary is forced by his father's illness to stay in Killdeer to look after the family business. As one might guess, he asks his best friend to look after his girl. The cliche ends here, however. Jane and Adam do not become involved with each other, but rather with Cleanth and Morgan, respectively. This couple in their thirties run the aptly named Lost Colony hotel. Jane and Adam are quickly sucked into the life of continuous excess-of drugs, alcohol, sex, psychological manipulation, and material consumption-that Cleanth and Morgan lead. Yet here too Payne avoids cliche. The relationships 
that develop among the four characters are complex and emotionally charged, not merely sordid and superficial. The charismatic Cleanth is the sun around whom the others revolve. He sees something of himself in the young Adam and for a time acts as his mentor, introducing him to various forms of self-indulgence and challenging his attitudes and values. At times Cleanth seems a very suave and modern Mephistopheles. In one cleverly written scene, Cleanth arrives wearing all black and driving a black Porsche, to play a game of tennis with the traditionally clad Adam. Cleanth wins. Adam finds Cleanth intriguing and his lifestyle seductive until its darker side begins to surface. During a camping trip, Morgan reveals the truth about Cleanth's past and present, shocking the reader no less than Adam and Jane. Only then do the younger couple realize that they have fallen in love with each other.

Many elements of Early from the Dance recall Thomas Wolfe, Eudora Welty, William Faulker, Carson McCullers, and Flannery O'Connor, among other Southern authors. Payne's use of language, emphasis on uncompromising honor and fealty, interest in the various social strata, evocative descriptions of nature, complex and often dark family relationships, fascination with insanity, and an implicit view of God as the source of fate and redemption, all hearken back to the author's regional heritage. The meticulous structure of the novel achieves a high level of suspense while offering tantalizing foreshadowing.

David Payne was born in Henderson, North Carolina, and graduated from Phillips Exeter Academy and the University of North Carolina at Chapel Hill. His first novel, the picaresque Confessional of a Taoist on Wall Street, won the 1984 Houghton Mifflin Literary Fellowship Award. Readers familiar with that work will recognize elements of the author's style and intellectual orientation in Early from the Dance. Both concern a male protagonist's literal and metaphysical search for clues to his past and for self-awareness and wholeness. Both novels reveal a fascination with charismatic personalities, father figures, moral ambiguity, power, domination, and killing. They present New York as simultaneously the promised land and a place of moral degradation. Finally, they share a careful structure and the skillful use of literary devices.

This complex and beautifully written novel is highly recommended for public and academic libraries across the state.

\section{GoO computers, inc. \\ ADVANCE Library System}

* Online Public Catalogue

* Cataloguing

* Circulation

* Acquisitions \& Serials Control

\section{The ADVANCE System is based on the hardware-independent PICK Operating System.}

Geac's Support Services include: Field Engineering offices, Educaion Services, Professional Services Project Management and a Library Assistant Desk.

515 N. Washington Street, 2nd Floor Alexandria, VA 22314 703.836 .0225

Walter C. Biggs, Jr., and James F. Parnell. State Parks of North Carolina. Winston-Salem: John F. Blair, Publisher, 1989. 339 pp. \$14.95. ISBN 089587-071-1 (pbk.).

If you are interested in standing on the tallest mountain peak east of the Mississippi River, scaling the highest sand dune on the east coast, fishing for bass or bluefish, or simply studying nature in peaceful surroundings, then this handy volume is especially for you.

Between the years 1916 and 1987, the state of North Carolina created some forty-one state parks, natural areas, and recreation areas, taking in nearly 135,000 acres of land. These sites range in size from 110 acres at Boone's Cave State Park in Davidson County to 17,449 acres at Pettigrew State Park near Creswell. They extend from the coastal plain in eastern North Carolina to the mountains in the western part of the state, and contain a wide variety of natural environments and facilities for lovers of the great outdoors. State Parks of North Carolina provides current facts and descriptive details on each of these stateowned land areas and is intended as a basic source of information concerning the state's 
parks. Its attractive format facilitates this purpose.

The guide is well organized, with each major unit in the parks system (state park, natural area, and recreation area) treated separately. Within the section entitled "State Parks," the parks are arranged by region (coastal plan, piedmont, and mountain), and then discussed alphabetically by the name of the park. Within the sections dealing with the natural areas and recreation areas (which are fewer in number), the areas are also treated alphabetically by name, but are not grouped according to geographic location. For each entry, the following information is given (if available): address, telephone number, size of park, date of establishment, location (including directions), principal park attractions, visitor activities, and the season when open to tourists. Text describes the site's historical background, hiking trails, local flora and fauna, available tourist facilities (campsites, swimming areas, picnic grounds, etc.), and other easily accessible attractions nearby. An appendix of common and scientific names of plants and animals noted in the text is included for the interested reader. Scatterred illustrations, maps, and a helpful index round out this entertaining source book for those desiring to spend time in the parklands.

The authors, who traveled over nine thousand miles in the course of three years visiting nearly every site they describe, write with great enthusiasm about the different kinds of experiences that abound in North Carolina's parks. In a concise and interesting manner, they make a point that no matter what type of outdoor activity one enjoys, endless choices are available in the impressive range of state parks.

Biggs and Parnell have obviously compiled this book as a labor of love for the parks of North Carolina and with the hope that others will share the joy of visiting these protected lands. In State Parks of North Carolina, they have presented the public with a helpful, eminently readable guide which can help its audience discover the beauty and wonder of some of North Carolina's most hidden and treasure-filled places. This book is a must for all North Carolina libraries.

Mike Shoop, Robeson County Public Library

William R. Trotter. Bushwhackers! The Civil War in North Carolina, Vol. II: The Mountains. Greensboro: Signal Research, Inc., 1988. 338 pp. $\$ 19.95$. ISBN 0-929307-02-X. Order from Piedmont Impressions, P.O. Box 29364, Greensboro, N.C. 27429.
No major battles occurred in the mountains of western North Carolina during the Civil War. When mountain society collapsed, the violence that took place was on a personal level, neighbor against neighbor. Plundering and mayhem were directed, not against some faceless mass, but against individuals and families known and often related to the combatants. Because western North Carolina was outside the major theaters of war and the engagements were usually small-scale, and because the mountains have generally been off the cognitive maps of southern and North Carolina historians, only recently have accounts of the western war been published beyond county and local histories. Bushwhackers, the second volume of William Trotter's three-volume history of the Civil War in North Carolina [Silk Flags and Cold Steel: The Civil War in North Carolina, Volume I: The Piedmont was reviewed in the Summer, 1989, issue of North Carolina Libraries], attempts to build a narrative by assembling a mosaic of fragmentary accounts while attempting "to minimize confusion ... without softening the ambiguities" (p. 3).

In his introduction the author provides an accurate evaluation of this volume: "If little has been uncovered in the preparation of this book that was totally unknown before, at least much of the information has been assembled into a coherent narrative that was scattered and buried in obscurity until now" (p. 3). Trotter's method has been to conflate accounts from three major works on the war in the mountains (Phillip Shaw Paludin's Victims, Vernon H. Crow's Storm in the Mountains, and Ina W. Van Noppen's Stoneman's Last Raid) with incidents from county and family histories and a variety of other sources. This has resulted in extensive coverage of the Shelton Laurel massacre, the activities of Thomas's Legion of Cherokee Indians, and General Stoneman's raid through western North Carolina, along with a number of less well-known events of the period.

Trotter sets the conflict within a framework of class divisions between the more wealthy, progressive, and generally pro-Confederate mountain elites of the towns and valley farms and the less wealthy, subsistence farming, conservative, and generally pro-Union mountainside and hollow dwellers. The narrative is persuasive in its depiction of the pervasive incidence of everyday violence in the western counties and convincing in its description of the divisive effects of conscription and the devastating results of impressment.

The author could have provided a more comprehensive and convincing account if he had used more of the readily available primary sources. 
North Carolina manuscript collections are full of letters from the period, along with several newspaper files available on microfilm. And the recent publication of The Papers of Zebulon Vance provides an accessible wealth of documents. There are also an annoying number of errors that reduce the credibility of the book. Some examples include spelling: Gregg for Gragg (p. 152); editorial confusion: Spring Laurel for Shelton Laurel (p. 225); geographic: going from Wilkesboro to Morgantown "through Swannanoa Gap" (p. 22); misreading of sources: John Ross "who would later become prominent in tribal affairs" was born in 1790 , died in 1866 and was not a member of the Thomas Legion (p. 65); and howlers: Levi (not Levy) Coffey, despite his name, was not Jewish (p. 153). The skirmish on Beech Mountain is recounted twice, first set in the spring of 1864 (pp. 161-164) and then, in a more condensed account, set correctly in the fall of 1864 (p. 173). The annotation is scanty and often leaves the reader without an indication of where to follow up an interesting event. In one instance a note miscites Arthur's Western North Carolina for his History of Watauga County. While none of these errors vitiate the author's basic arguments or narrative, they suggest sloppy research and editing.

Although many historians will argue with some of his hasty generalizations about Appalachian society and his accounts of Cherokee history, Trotter has provided a readable account of the violent events that divided mountain people during and after the Civil War that will suit the needs of some readers, but libraries should acquire the books by Paludin and Crow before purchasing this one.

Eric J. Olsom, Appalachian State University.
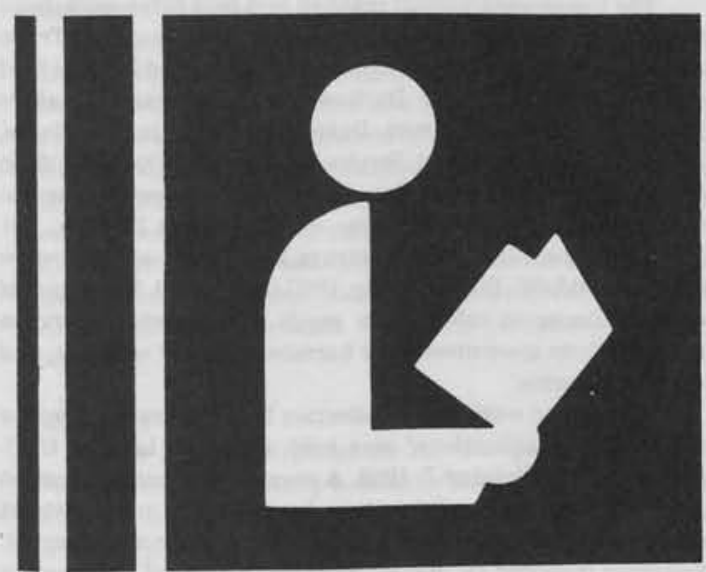

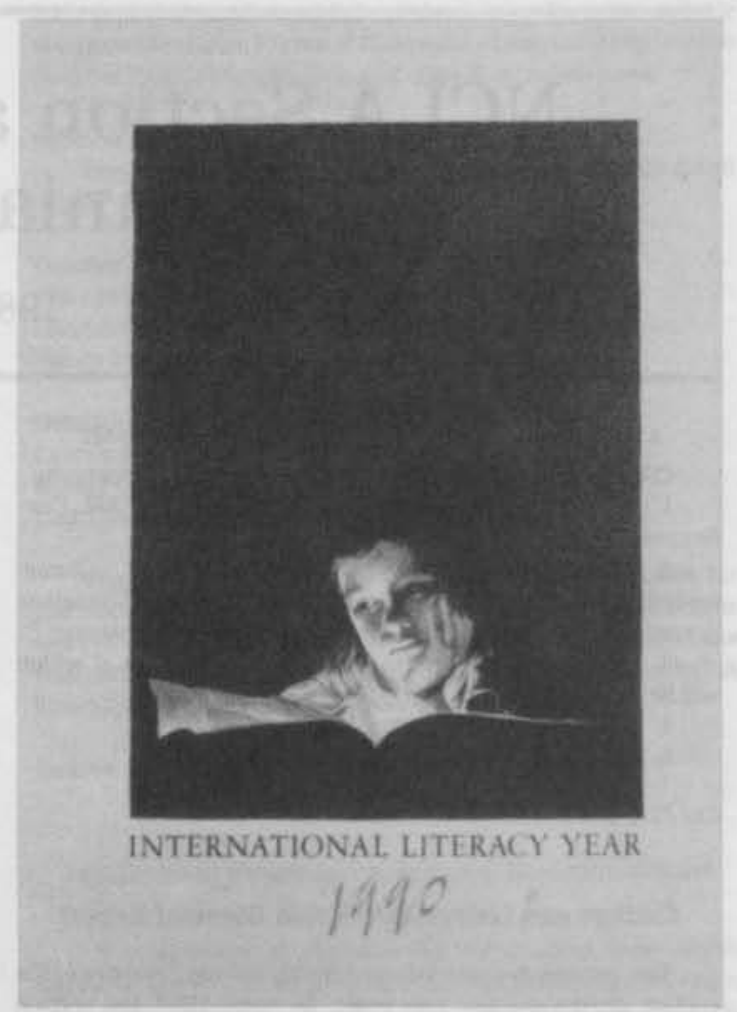

Barry Moser has created a poster on 1990 International Liter. acy Year for the Children's Book Council. The poster, measuring $24^{\prime \prime} \times 321^{\prime \prime}$, is in six colors. It costs $\$ 15.00$ and is shipped rolled in a mailing tube. Send a $25 \mathrm{e}$ stamped, self-addressed envelope to CBC (P.O. Box 706, New York, NY 10276-0706) for Current Materials Brochure for details.

\section{Subscription Order}

\section{Please place mailing label from your issue here.}

North Carolina Libraries is published four times a year by the North Carolina Library Association. Subscription: $\$ 32$ per year; $\$ 50$ foreign countries. Single copy $\$ 10$. Address new subscriptions, renewals, and related correspondence to Frances B. Bradburn, editor; North Carolina Libraries, Joyner Library, East Carolina University, Greenville, NC 27858 or call (919) 757-6076. (For membership information, see address label on journal) 